The Nature of Race 



\section{The Nature of Race}

H O W S C I E N T I S T S T H I N K

A N D TEA G H A B O U T H U M N

D I F F E R E N C E

A N N M O R N I N G

甲

U N I V ER S I T Y O F C A L I F OR NIA PRESS

Berkeley Los Angeles London 
University of California Press, one of the most distinguished university presses in the United States, enriches lives around the world by advancing scholarship in the humanities, social sciences, and natural sciences. Its activities are supported by the UC Press Foundation and by philanthropic contributions from individuals and institutions. For more information, visit www.ucpress.edu.

University of California Press

Berkeley and Los Angeles, California

University of California Press, Ltd.

London, England

(C) 2011 by The Regents of the University of California

Library of Congress Cataloging-in-Publication Data

Morning, Ann Juanita, 1968-

The nature of race : how scientists think and teach about human difference / Ann Morning.

p. $\mathrm{cm}$.

Includes bibliographical references and index.

ISBN 978-0-520-27030-5 (cloth : alk. paper)

ISBN 978-0-520-27031-2 (pbk. : alk. paper)

1. Race. 2. Racism in anthropology. 3. Racism in education.

4. Racism in textbooks. I. Title.

GN269.M675 2011

$305.8-\mathrm{dc} 22$

2011000291

Manufactured in the United States of America

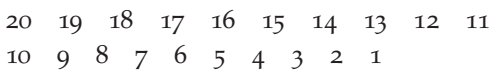

This book is printed on Cascades Enviro 100, a 100\% post consumer waste, recycled, de-inked fiber. FSC recycled certified and processed chlorine free. It is acid free, Ecologo certified, and manufactured by BioGas energy. 